OPEN ACCESS

Edited by:

Anna Mystkowska-Wiertelak, University of Wrocław, Poland

Reviewed by:

Marek Derenowski, Adam Mickiewicz University, Poland

Katarzyna Papaja,

University of Silesia in Katowice,

Poland

*Correspondence:

Bernard Gumah

bernsure@hotmail.com

Specialty section:

This article was submitted to Educational Psychology, a section of the journal

Frontiers in Education

Received: 22 June 2021 Accepted: 20 August 2021 Published: 13 September 2021

Citation:

Gao Y, Gumah B, Kulbo NB, Addo PC, Kulbo DB and Aziabah MA (2021) Predictors of Teachers' Self-Efficacy in Teaching EFL: An Examination of "Nativeness" and Teachers' Training. Front. Educ. 6:729271. doi: 10.3389/feduc.2021.729271

\section{Predictors of Teachers' Self-Efficacy in Teaching EFL: An Examination of "Nativeness" and Teachers' Training}

\author{
Yan Gao ${ }^{1}$, Bernard Gumah ${ }^{2 *}$, Nora B. Kulbo ${ }^{2}$, Prince Clement Addo ${ }^{3}$, Dora B. Kulbo ${ }^{4}$ and \\ Maxwell A. Aziabah ${ }^{5}$ \\ ${ }^{1}$ School of Foreign Languages, Huzhou University, Chengdu, China, ${ }^{2}$ School of Management and Economics, University of \\ Electronic Science and Technology of China, Chengdu, China, ${ }^{3}$ Faculty of Applied Sciences and Mathematical Education, \\ Akenten-Appiah Menka University of Skills Training and Entrepreneurial Development, Kumasi, Ghana, ${ }^{4}$ School of Business, \\ Kwame Nkrumah University of Science and Technology, Kumasi, Ghana, ${ }^{5}$ Department of Community Development, SD Dombo \\ University of Business and Integrated Development Studies, Wa, Ghana
}

The study aimed to establish the link between teacher training and "nativeness" on teachers' self-efficacy in teaching English as a second language. By applying a teacher's sense of efficacy scale, we measured the self-efficacy of a total of 281 foreign teachers in Chengdu, China. We adopted MANOVA and tested the influence of "nativeness" and teachers' training on teachers' self-efficacy. Our analysis shows that while being a native speaker does not necessarily influence a teacher's self-efficacy, trained teachers have higher self-efficacy than untrained teachers. Thus, the current study lends credence to the view that language proficiency should not be allied with being a language teacher. Instead, educational administrators and policymakers should focus on language teachers' professional development rather than emphasizing the native/nonnative teachers' distinction.

Keywords: EFL teacher, teacher's self-efficacy, teaching English (as a foreign language), teacher training, nativeness perception

\section{INTRODUCTION}

English remains the first global language and a popular international language in China (Gil, 2011). As a result, understanding and speaking English is an added advantage to many Chinese in light of the new 'one belt and one road' policy, one of many policies that seek to extend China's global relationship with the rest of the world (Aoyama, 2016). However, connecting China to other countries will require the English language for communication since the Chinese language does not enjoy wide acceptance. For this reason, the study of English is a compulsory subject from the basic to the tertiary levels in China (Braine, 2012). There is, therefore, a significant burden on authorities to meet the demand for English teachers for academic and non-academic purposes. According to Zheng and Zhang (2014), in 2013 alone, there were about 300 million Chinese learning English in China, with only about 100,000 foreign English teachers. Similarly, there was a $298 \%$ growth in China's English education market between 2016 and 2017 alone, from $¥ 123.6$ billion to $¥ 489.7$ billion (Farrell, 2018). Generally, there is an imbalance between the demand for, and the supply of qualified professional English teachers, compelling schools to fill this gap with unqualified persons.

Two main channels exist for recruiting teachers to teach English as a foreign language (EFL) in China: State-sponsored programs in TEFL and free training for Bachelor's or Master's holders of translation or English literature (Eslami and Fatahi, 2008). In the absence of qualified foreign 
teachers, unqualified foreigners are used. In such situations, peoples' belief in their abilities and capabilities play a significant role in determining these teachers' output.

Self-efficacy plays a vital part in teaching because of its ability to either help or hinder performance for both professional and non-professional teachers arriving in a new environment (Bandura, 2010). In this study, a professional teacher refers to one, who, having gone through an organized and certified program or having satisfactorily completed a prescribed course of training at a higher education institution, or such other course or courses which educational stakeholders determine as satisfying requirements for classification as a teacher, is duly qualified to carry out the duties of a teacher/educator. In this paper, we use "professional teacher" and "trained teacher" interchangeably. As part of its culture of learning, the typical approach to TEFL in China has been a combination of the audiolingual and grammartranslation methods ( $\mathrm{Hu}, 2002)$. This is mainly characterized by cross-linguistic comparisons and a detailed study of grammar by memorizing vocabulary and sentence structure. There is a direct contrast with communicative language teaching (CLT), primarily employed in English language teaching and learning. In this teaching method, meaning is primary, and the focus should be on teaching communicative functions, rather than only linguistic knowledge and the capacity to use structural patterns (Brown, 2001). The CLT approach is considered an alien methodology at variance with the traditional Chinese teaching method condensed into the ' 4 R's and 4 M's' (Brown, 2001, p. 100). The four Rs are reception, repetition, reproduction, and review. The four M's represent memorization, meticulosity, mastery, and mental activeness. In $\mathrm{Hu}$ (2005) view, the significant factors that pose a potential conflict in CLT's application in the Chinese culture of learning are the embodiment of different and opposing philosophies in teaching and learning. Therefore, teaching and learning in China are different from the West; hence, teachers need to grasp the country's teaching philosophy to succeed. Thus, foreign teachers' self-efficacy will play a vital role in successful teaching.

An emerging argument is that target language proficiency should not be associated with nativeness; rather, adequate preparedness through training should be one of the main criteria for assessing native and non-native teachers (Medgyes, 1992; Braine, 2010). Choi and Lee (2016) suggest that professional training and target language proficiency form the sources of teacher's self-confidence, which are vital requirements for second language teachers. They note that the preferred teacher has both traits, whereas teachers with insufficient levels are least preferred. These claims are supported by the existence of literature on language teacher's proficiency (Hoang and Wyatt, 2021), teachers' training (Shum et al., 2020), and self-efficacy.

While admitting there have been studies in the Chinese setting (Cheung, 2008) similar to the current endeavor, none of them combines the bundle of variables used in the current study. Given that an estimated $80 \%$ of language teachers are non-native English speakers (Braine, 2018), we follow Choi and Lee (2016) conclusion and test whether being trained and/or being a native speaker of the target language influences the three dimensions of self-efficacy. The study, therefore, presents a two-fold dimension to understanding the effects of English language teachers' self-efficacy as far as China is concerned. Using multivariate analysis of variance (MANOVA), the paper assesses these relationships to establish whether teachers' training and/or nativeness result in higher self-efficacy and better performance.

\section{THEORETICAL BACKGROUND}

\section{Teachers' Self-Efficacy}

Self-efficacy, by Bandura (2010, p. 1), “is defined as people's beliefs about their capabilities to produce chosen levels of performance that exercise influence over events that affect their lives." To Maddux (2002), self-efficacy is what individuals believe they can do with their abilities and skills under certain conditions. Teacher self-efficacy may be explained as teachers' personal beliefs in carrying out activities through adequate planning and organizing to attain set educational goals (Skaalvik and Skaalvik, 2010). It is also about how teachers utilize their competence and professional discipline to influence students' behavior, knowledge, and values (Tschannen-Moran and Hoy, 2001). It thus depicts what teachers can do in a particular situation, not what they have accomplished or why it was accomplished in the past (Goddard et al., 2004). The self-efficacy of teachers involves the choice of activities, effort, and persistence. People with minimal self-efficacy are unlikely to engage in challenging tasks. In contrast, individuals with a high sense of self-efficacy are more persistent and enduring even when they face difficulties.

The work by the Research and Development (RAND) corporation is the foundation of teachers' self-efficacy. It is the degree to which teachers believed in whether their ability to take charge of reinforcement was within their remit or the environment (Rotter, 1966). Student motivation and performance were presumed to be significant reinforcers for teaching behaviors. In the RAND researchers' view, the expectation is that high levels of teachers' self-efficacy could strongly influence students' motivation and achievement. A second view of the theory emerged as a result of the research of Bandura (1977a). In his view, teachers' self-efficacy is a cognitive process in which individuals build self-beliefs about their ability to accomplish a task within acceptable limits. This sense of self-belief controls the energy expended and the endurance and persistence required to face and overcome challenges. These two views of the theory form the underpinnings of teachers' self-efficacy but undoubtedly create gaps in the theory's clarity. Some of these issues border on whether teachers' self-efficacy is a one-size-fits-all or specific to certain conditions and whether the theory needs refinement to capture other vital assessment areas (Tschannen-Moran et al., 1998). Teachers' self-efficacy is also related to classroom organization, levels of persistence on a task, instructional strategies, questioning techniques, innovation, degree of risktaking, management of students' on-task time, and teacher feedback to students (Gibson and Dembo, 1984). The TSES concentrates on classroom management, student engagement 
activities, and instructional strategies as the three cardinal areas of teachers' self-efficacy.

Hoy and Weinstein (2015) describe classroom management as an overarching term comprising creating a productive, orderly learning environment to influence students' behavioral changes and guide them to accomplish their objectives. Recent studies and theoretical developments have resulted in a refinement of classroom management along two continuums: structure versus chaos; and autonomy support versus control (Jang et al., 2010). Furthermore, countless novice teachers believe that handling their classroom is a precondition to teaching content (Cochran-Smith and Villegas, 2016); nonetheless, studies have demonstrated that novice teachers have weaker classroom climates than experienced teachers. Gibson and Dembo (1984) suggest that classroom management strategies influence teachers' perceptions of their competence. Teachers with higher perceptions of self-efficacy tend to have betterplanned classrooms, more organized, student-centered, accommodating, and amenable to new ideas (Anthony and Kritsonis, 2007) and highly effective in using classroom management skills (Lazarides et al., 2020). Teachers with less classroom management skills tend to have classrooms characterized by aggression (Shernoff and Kratochwill, 2007). Higher self-efficacy beliefs were more associated also with higher ratings of closeness and lower ratings of conflict with students across all grades (Hajovsky et al., 2020). Henson (2001) finds that more practical teachers, use the enhanced classroom management approach (seating, creating routines, instituting reward systems, using technology), while Tschannen-Moran et al. (1998) report that a teacher's self-efficacy determines his/ her inclination to work with students with difficulties instead of referring them to special education programs. Similarly, Landrum and Kauffman (2015), and Putri and Refnaldi (2020) consider the use of rewards and punishment as alternatives in managing classrooms. They intimate that teachers' main reason for adopting such an approach is to ensure their efficiency since it is an easy way of managing a student's misbehavior, giving teachers a feeling of control.

Bandura (2010) proposes four self-efficacy sources: mastery, vicarious experiences, physiological disposition, and social persuasion. According to Goddard et al. (2004), mastery experience is the most common and direct self-efficacy source. Behavior, personal and environmental factors influence selfefficacy (Bandura, 2010). Mastery experience continuously dominates as a strong force in nurturing teachers' self-efficacy (Bandura, 1997a). Engaging students in classroom lessons is a measure of mastery experience. Therefore, there is a significant reinforcement of teachers' self-efficacy when observing students involved in in-class activities. When students have low interests or are not engaged, teachers' responsibilities increase (Ross et al., 1996), undermining their sense of efficacy.

Self-efficacy is specific to each situation and is applied differently among individuals. For example, teachers' selfefficacy in a classroom may vary according to the subject taught and the students' level. Individuals differ in how they nurture their self-efficacy and the intensity of such nurturing within their specialty area (Bandura, 2010). For example, a teacher could have high self-efficacy in classroom management but low self-efficacy in student engagement activities. Therefore, the existence of a multi-purpose measure of perceived selfefficacy is a mirage. According to Bandura (1977b), the "onesize-fits-all" method usually has incomplete predictive and explanatory values because the items in an all-purpose test may have little or no bearing on the task. Moreover, generalized scales ordinarily neglect an individual's specific demands and situations to serve all needs, leading to ambiguity in measurement.

The predisposition of teachers, influenced by their initial preparation, physical and emotional condition, and external factors such as the background and demeanor of colleagues, contribute to the level of self-efficacy (Schnuck et al., 2014). In addition, teachers' qualities such as sex, grade, level taught, and experience also play a significant role in determining their selfefficacy (Berger et al., 2018). Generally, the ability to succeed raises teachers' self-efficacy, while failure decreases it.

In the literature, two major scopes of teachers' perceived efficacy (TES) are discussed: General Teaching Efficacy (GTE) and Personal Teaching Efficacy (PTE) (Tschannen-Moran and Hoy, 2001). PTE signifies a teacher's belief about their ability to change a students' performance, while GTE encompasses the teachers' beliefs about the influence of external factors and the teacher's ability to affect students' performance. Conceptual questions have been raised mostly about the GTE, which focuses more on teachers' ability to influence outcomes and is noted as a measure of locus of control (Rotter, 1966), a justification for its inaccurate measurement of self-efficacy (Faez and Karas, 2017). However, the development of what is currently known as the teacher's sense of efficacy scale (TSES) has improved the methodological concerns in the TES (Wyatt, 2014).

According to Wheatley (2002), doubt and uncertainty are sometimes beneficial to a person's self-efficacy. The foundation of Wheatley's challenge to Bandura (1997b) idea is that self-efficacy doubts are necessary for teachers' learning and improvement processes. For example, this uncertainty could emanate from a test on teachers' beliefs about their current tasks. To mitigate the impact of teacher's self-efficacy doubts, Wheatley (2002) proposes follow-up coaching.

\section{Native and Non-native Language Speakers}

The main criterion for describing a person as a native speaker considers the circumstances of acquisition; thus, a native speaker is perceived as someone who acquires a language at childhood (Davies, 2003). Native language represents "the language a person acquires in early childhood because it is spoken in the family and/ or it is the language of the country where he or she is living" (Richard, 1985, p. 241). This means that it is possible to be a native speaker of two or more languages if acquired early in childhood.

Brutt-Griffler and Samimy, (2001) think that "nativeness" is a social construct rather than a linguistic category. The description of English speakers as "native" or "non-native" speakers hinges upon several social considerations, such as the notions of what and how a native speaker should look or sound like. To Mesthrie and Bhatt (2008, p. 36), "the distinction between a native and 
non-native speaker of English - long taken for granted in linguistics - is being increasingly called into question in World English research."

Parental guidance affects language development for native speakers, as language learning begins through engagement with caregivers and parents. According to Gass et al. (2010), being exposed to a language through language input and instruction and socialization with, for instance, Englishspeaking peers helps develop the language. According to Kachru (1997), this category comprises speakers who usually set the standards for English-language proficiency, particularly those from countries where English is the native language for most people, such as the US and the UK. Following this, Kachru (1997) proposes three descriptions of English speakers around the world. Countries that recognize English as a native language are referred to as the Inner Circle (e.g., Canada, Britain, Australia, Ireland, North America). The Outer Circle treats English as a second language or an official language (e.g., India, Malaysia, Ghana, South Africa, Philippines). The Expanding Circle are the countries that accept English as a foreign language (e.g., China, Japan, Republic of Korea, Russia). Based on this classification, citizens of countries belonging to the outer and expanding circles are non-native speakers.

Non-native speakers either speak or learn English as a second language (e.g., Netherlands) or as a foreign language (e.g., China) (Kachru, 1997). A non-native speaker does not have the opportunity to develop through the initial processes of native speakers. It has been claimed that non-native English-speaking teachers (NNESTs) face problems in terms of a lack of confidence and students' biased attitude (Reis and Johnson, 2010), even though they are the majority of the English language teachers. Studies insist that foreign language teachers should hear, understand, speak, read, and write in the target language with a minimum proficiency level, either advanced or higher (Omaggio and Higgs, 1984). The command of a language is a mark of a good teacher. Teaching qualifications, exposure to native speakers, and living in an English-speaking country all affect teachers' knowledge of and self-image regarding the language; the higher the NNEST's proficiency in English, the more confident they become (Reves and Medgyes, 1994).

The goal of learning English varies in every country. For example, it is used primarily for communication in Venezuela, whereas it is for business communication in China. In Venezuela, upon graduation, EFL teachers are hired to teach in high schools without passing an exam or obtaining a certificate that shows their English competency (Chacón, 2005). Venezuela, also, places great emphasis on descriptive linguistics. Thus, the study of language at the sentence level overlooks the social nature of language as a means of communication and interaction (BruttGriffler and Samimy, 1999). Generally, teachers in Venezuela may not acquire the communicative competence to perform in the four primary language skills: writing, reading, listening and speaking. Without this competency, teachers find themselves unable to use communicative language teaching (CLT) in their English classes (Li, 1998) as they do not consider themselves competent in English and tend to have a low sense of self-efficacy. In Hong Kong, it was realized that NNESTs were influential in pedagogy but were found to be weak linguistically. On the other hand, NESTs had a perceived linguistic strength but had pedagogical weaknesses ( $\mathrm{Ma}, 2012)$.

Inadequate language knowledge can influence the teacher's selfesteem and professional status and interfere with simple teaching procedures. Perceived language proficiency is of concern to NNESTs and impacts their professional self-esteem and confidence (BruttGriffler and Samimy, 1999). CLT's implementation requires EFL teachers to be competent in the English language to teach it in Iran. EFL teachers are expected to use English with functional ability in communicating across language skills (Eslami and Fatahi, 2008). Research points to perceived language proficiency as an essential factor for NNEST since it impacts their professional confidence and self-esteem (Brutt-Griffler and Samimy, 1999).

In concluding this section, we adopt the words "native" and "non-native," mostly from Kachru (1997). Native English speakers are considered mainly those who use English as their first and mother tongue and are recognized as such. On the other hand, non-native speakers have another language as their mother tongue or L1 and have studied English as a second or foreign language and sometimes adopt it as an official language. Based on the foregoing, we hypothesize that:

H1: Professionally trained teachers have higher self-efficacy than untrained teachers.

H2: Native English-speaking teachers have higher self-efficacy than non-native English teachers.

\section{METHODS}

\section{Participants}

The study population is foreigners in China, with the sample being foreign English language teachers in kindergartens and training schools living in Chengdu. Language Training Schools (popularly called training schools) in the Chinese context are designed for persons who are interested in out of formal school English language training. They train persons of all ages to speak, read and write in English. The participants have taught or teach English in public and private kindergartens and English language training schools. The recruitment of the study group was first through contacts with training schools and convenience sampling. Next, an online questionnaire was distributed to principals of training schools contacted as well as general and known teachers' social media platforms, with specific guidelines on the target groups. In all, two hundred and eighty-one (281) questionnaires were returned out of an expected number of 400 , representing a response rate of $61.8 \%$. The variables were measured using self-reported assessments.

The study adopted and modified the 12 item Teacher Sense of Efficacy Scale (TSES) proposed by Tschannen-Moran et al. (1998), which is used not only for general teaching but also for language teacheing (Chacón, 2005; Eslami and Fatahi, 2008; Swanson, 2012; Clark, 2016; Berger et al., 2018; Azari Noughabi and Amirian, 2021; Gumah et al., 2021). Although other self-efficacy scales exist specifically for language teachers, such as the Second/Foreign Language Teacher Efficacy Scale (S/FLTES) developed and used 
by Swanson (Swanson, 2012; Url and Swanson, 2012), the S/FLTES is still new and needs further development and testing on a more extensive and diverse S/FL teaching population. The TSES was considered appropriate because of the aspects of teaching that it measures and its extensive use and validity. Bandura (2006) points out that self-efficacy scales should measure what they purport to measure and have both discriminative and predictive validity. Hence the reason for the modification. Statement such as I am able to calm down a student who is noisy and disruptive in my English class (classroom management), I can motivate students who show low interest in learning English (student engagement), and I can use a variety of assessment strategies in my English class (instructional strategies) constituted the measurement items. Respondents were thus mandated to indicate their level of agreement to each statement from 1 (strongly disagree) to 5 (strongly agree).

The measurement of teacher training was executed through answers to a self-reported assessment such as Have you gone through formal teacher training?, which required a "yes" or "no" answer. Formal teacher training means being trained for not less than 1 year in instructional and methodological approaches to teaching based on a specific country's accepted training curriculum. This does not necessarily mean being trained only to teach a language but could include other subjects while excluding online TESOL/TEFL training.

Similarly, "nativeness" was measured by answering "yes" or "no" to the question, Is English the first language or the mother tongue (L1) of your country? In response to this question, respondents were expected to indicate whether they were born and bred in a native English-speaking country and/or have English as a first language (L1). Again, this shows whether English is their native language or not based on the operational definition.

\section{Reliability and Internal Consistency}

In testing the reliability of the TSES, Cronbach's alpha ( $\alpha$ ) values were used. Table 1 provides an overview of the reliability level emerging from Cronbach's alpha statistics. Each of the TSES dimensions (instructional strategies, classroom management, and student engagement activities) showed high reliability and internal consistency based on an acceptable standard of $\alpha<$ 0.70 . An examination of the item-total statistics table indicates that none of the variables examined obtained values $<0.30$.

\section{ANALYSIS}

We used MANOVA to compare native English speakers with trained teachers on their self-efficacy levels in teaching English. MANOVA measures several dependent variables (DVs) in a

\begin{tabular}{lccccc}
\hline TABLE 1 | Reliability statistics. & & & & & \\
\hline TSES & $\begin{array}{l}\text { No. of } \\
\text { items }\end{array}$ & Alpha ( $\mathbf{\alpha})$ & GFI & TLI & CFI \\
\hline Instructional strategies & 4 & 0.84 & 0.928 & 0.980 & 0.985 \\
Classroom management & 4 & 0.92 & 0.857 & 0.920 & 0.936 \\
Student engagement activities & 4 & 0.91 & 0.898 & 0.952 & 0.966
\end{tabular}

single experiment, with a better chance of discovering which factor is significant. It also protects against Type I errors that can occur in independent multiple ANOVAs and reveals differences that ANOVA tests cannot discover.

The descriptive statistics in Table 2 show that more male respondents (62.6\%) than females were engaged in teaching jobs in Chengdu-China. Among this group of respondents, the majority (63.4\%) were within 25-34 years old, while respondents aged 55 years or more represented only $2 \%$. There was a significant difference between trained and untrained teachers (57.6 and $42.4 \%$, respectively). Trained teachers (162) have teaching experience ranging from less than 5 years $(50.6 \%)$ to more than 20 years (3.7\%). Individuals with TEFL training represented 76.9\%, most being native English speakers (59.1\%). Foreign teachers had been engaged from less than 6 months to over 5 years, with the majority having worked for between one and 5 years $(40.9 \%)$.

In Table 3, we show the relation between the variables of interest in a correlation matrix. All other variables were significant except for nativeness and student engagement activities that did not show any statistical significance. Thus, the level of correlation does not pose any collinearity problem.

The descriptive statistics presented in Table 4 contain the overall and group means, standard deviations, and the results for each independent variable (IV) and dependent variable (DV). The Table shows a higher mean score for trained teachers who are native speakers in classroom management (29.11) and a mean score of 29.46 in instructional strategies for teachers who are neither untrained nor native speakers.

A homogeneity test using Box's M-test of equality of covariance matrices showed a $p$-value of 0.03 , which means significant differences exist among the independent variables (IV) in the covariance matrices. This is against the assumption of MANOVA, but the sample size and the unequal values of each observation could explain the discrepancy. Since the assumption is violated, we used Pillai's Trace for the multivariate test (Olson, 1976). This test is considered a powerful and robust statistic for general use, particularly for departures from assumptions such as assumption of homogeneity of variance. It is also a good choice when you have uneven cell sizes or small sample sizes (Pillai, 1955) We controlled for age, sex, and education to test the IVs' effect on the DVs. Table 5 shows the multivariate test results, indicating significant relations between trained teachers and the IV $\left(F=5.17^{* * *}\right.$, observed power $\left.=95.9 \%\right)$, and the DV and the IV $(F=1.45$, observed power $=51.2 \%)$. This shows that nativeness did not influence self-efficacy.

We noted that there was a positive relationship between trained teachers and instructional strategies $(F=8.92, p<0$. 01 , partial $\eta 2=0.032$, power to detect the effect $=90.9 \%$ ). Classroom management was also positively influenced by training $\left(F=6.79, p<0.05\right.$, partial $\eta^{2}=0.025$, power to detect the effect $=83 \%$.). There was a statistical significance in the relationship between trained teachers and student engagement activities $(F=14.52, p<0.01$, partial $\eta 2=0.051$, power to detect the effect $=98.4 \%$ ). Based on these findings, the combined effect, as shown in table 5, supports H1. The second IV (nativeness) did not produce any statistical significance in its 
TABLE 2 | Background information of respondents.

\begin{tabular}{|c|c|c|c|}
\hline & Variable & Frequency & Percent \\
\hline \multirow[t]{2}{*}{ Sex } & Male & 176 & 62.6 \\
\hline & Female & 105 & 37.4 \\
\hline \multirow[t]{5}{*}{ Age (years) } & Below 25 & 34 & 12.1 \\
\hline & $25-34$ & 178 & 63.4 \\
\hline & $35-44$ & 52 & 18.5 \\
\hline & $45-54$ & 13 & 4.6 \\
\hline & 55 and above & 4 & 1.4 \\
\hline \multirow[t]{4}{*}{ Education } & High school & 6 & 2.1 \\
\hline & Diploma & 13 & 4.6 \\
\hline & Bachelor & 145 & 51.6 \\
\hline & Masters & 114 & 40.6 \\
\hline \multirow[t]{5}{*}{ Years on the Job } & Below 6 months & 63 & 22.4 \\
\hline & $6-12$ months & 82 & 29.2 \\
\hline & Above 13 months but below 60 months & 115 & 40.9 \\
\hline & 60 months and above & 21 & 7.5 \\
\hline & $\mathrm{PhD}$ & 3 & 1.1 \\
\hline \multirow[t]{2}{*}{ Have you gone through formal teacher training? } & No & 119 & 42.4 \\
\hline & Yes & 162 & 57.6 \\
\hline \multirow[t]{5}{*}{ If yes, how many years of teaching experience do you have? } & Less than 5 & 82 & 50.6 \\
\hline & $5-10$ & 39 & 24.0 \\
\hline & $10-15$ & 19 & 11.7 \\
\hline & $15-20$ & 16 & 9.9 \\
\hline & More than 20 & 6 & 3.7 \\
\hline \multirow[t]{2}{*}{ Do you have a TEFL certificate } & No & 65 & 23.1 \\
\hline & Yes & 216 & 76.9 \\
\hline \multirow[t]{2}{*}{ Is English the first language or mother tongue $(L 1)$ of your country? } & No & 115 & 40.9 \\
\hline & Yes & 166 & 59.1 \\
\hline
\end{tabular}

$N=281$

TABLE 3 | Correlation between variables.

\begin{tabular}{llccccl}
\hline & \multicolumn{1}{c}{ Variables } & $\mathbf{1}$ & $\mathbf{2}$ & $\mathbf{3}$ & $\mathbf{4}$ & $\mathbf{5}$ \\
\hline 1 & Trained teacher & 1 & & & & \\
2 & Native speaker & $0.134^{\star \star}$ & 1 & & & \\
3 & Instructional Strategies & $0.199^{\star \star \star}$ & $0.103^{\star}$ & 1 & & \\
4 & Classroom Management & $0.188^{\star \star \star}$ & $0.096^{\star}$ & $0.576^{\star \star \star}$ & 1 & \\
5 & Student Engagement & $0.220^{\star \star \star}$ & 0.033 & $0.648^{\star \star \star}$ & $0.463^{\star \star \star}$ & 1
\end{tabular}

Note: indicates significance at ${ }^{* *} \mathrm{p}<0.001 ;{ }^{* *} \mathrm{p}<0.01 ;{ }^{*} \mathrm{p}<0.05$.

\begin{tabular}{lccccc}
\hline \multicolumn{1}{l}{ TABLE 4 I Descriptive statistics. } & & & & \\
\hline Variable & Trained & Native & Mean & SD & Frequency \\
\hline Instructional Strategies & No & Yes & 28.27 & 3.602 & 87 \\
& & No & 29.46 & 3.659 & 46 \\
& Yes & Yes & 29.97 & 3.808 & 77 \\
& & No & 30.45 & 3.468 & 71 \\
Classroom Management & \multirow{2}{*}{ No } & Yes & 26.41 & 5.290 & 87 \\
& & No & 28.43 & 5.739 & 46 \\
& Yes & Yes & 29.11 & 4.822 & 77 \\
Student Engagement & & No & 28.96 & 4.269 & 71 \\
& \multirow{2}{*}{ No } & Yes & 26.95 & 4.488 & 87 \\
& & No & 26.93 & 5.908 & 46 \\
& \multirow{2}{*}{ Yes } & Yes & 28.60 & 4.132 & 77 \\
& & No & 29.55 & 4.249 & 71 \\
\hline
\end{tabular}

Note: $\mathrm{N}=281$.
TABLE 5 | Multivariate tests results.

\begin{tabular}{lccccc}
\hline Variable & Value & F & Sig. & Partial $\boldsymbol{\eta} \mathbf{2}$ & Observed power \\
\hline Trained & 0.055 & 5.17 & 0.002 & 0.05 & 0.959 \\
Native & 0.016 & 1.45 & 0.227 & 0.01 & 0.512
\end{tabular}

Note: significance level at $\mathrm{p}<0.01$.

relationship with the three dimensions of self-efficacy. For this reason, we conclude that $\mathbf{H} \mathbf{2}$ is not supported.

We used the tests of between-subject effects (Table 6) to confirm the hypotheses by checking the IV's individual effect on the DV.

\section{DISCUSSION}

Trained foreign teachers become the preferred candidates for employment opportunities because of their knowledge and experience. In other words, they have better teaching skills and understand both child psychology and teaching methodologies based on teacher training modules. A requirement in this section for issuing a work permit or a work visa for a teaching job is that the applicant should have a teaching certificate (Zheng and Zhang, 2014). From the analysis, trained teachers have higher self-efficacy levels than untrained teachers. This finding is consistent with prior studies that have 
TABLE 6 | Tests of between-subjects effects.

\begin{tabular}{|c|c|c|c|c|c|c|}
\hline Source & Dependent variable & Mean square & $\boldsymbol{F}$ & Sig. & Partial $\eta 2$ & Observed power ${ }^{a}$ \\
\hline \multirow[t]{3}{*}{ Corrected model } & IS & 40.66 & 3.07 & 0.01 & 0.06 & 0.95 \\
\hline & $\mathrm{CM}$ & 64.92 & 2.57 & 0.02 & 0.05 & 0.91 \\
\hline & SE & 95.71 & 4.66 & 0.00 & 0.09 & 0.99 \\
\hline \multirow[t]{3}{*}{ Intercept } & IS & $4,839.41$ & 365.75 & 0.00 & 0.57 & 1.00 \\
\hline & $\mathrm{CM}$ & $4,920.50$ & 195.06 & 0.00 & 0.42 & 1.00 \\
\hline & SE & $3,375.89$ & 164.40 & 0.00 & 0.37 & 1.00 \\
\hline \multirow[t]{3}{*}{ Sex } & IS & 4.76 & 0.36 & 0.55 & 0.01 & 0.16 \\
\hline & $\mathrm{CM}$ & 10.24 & 0.40 & 0.52 & 0.01 & 0.17 \\
\hline & SE & 31.24 & 1.52 & 0.22 & 0.01 & 0.34 \\
\hline \multirow[t]{3}{*}{ Age } & IS & 3.63 & 0.27 & 0.60 & 0.01 & 0.15 \\
\hline & $\mathrm{CM}$ & 0.06 & 0.01 & 0.96 & 0.01 & 0.10 \\
\hline & SE & 13.35 & 0.65 & 0.42 & 0.01 & 0.21 \\
\hline \multirow[t]{3}{*}{ Education } & IS & 27.83 & 2.10 & 0.15 & 0.01 & 0.42 \\
\hline & $\mathrm{CM}$ & 1.08 & 0.04 & 0.84 & 0.01 & 0.11 \\
\hline & SE & 191.25 & 9.31 & 0.00 & 0.03 & 0.92 \\
\hline \multirow[t]{3}{*}{ Trained } & IS & 118.08 & 8.92 & 0.00 & 0.03 & 0.91 \\
\hline & $\mathrm{CM}$ & 171.36 & 6.79 & 0.01 & 0.02 & 0.83 \\
\hline & SE & 298.22 & 14.52 & 0.00 & 0.05 & 0.98 \\
\hline \multirow[t]{3}{*}{ Native } & IS & 24.70 & 1.86 & 0.17 & 0.01 & 0.39 \\
\hline & $\mathrm{CM}$ & 50.72 & 2.01 & 0.16 & 0.01 & 0.41 \\
\hline & SE & 0.14 & 0.01 & 0.93 & 0.01 & 0.10 \\
\hline
\end{tabular}

Note: significance level at $\mathrm{p}<0.01$.

established that training and professional development influence teachers' self-efficacy (Kraut et al., 2016; Clark and Newberry, 2019). It also supports Bandura (1997a) assertion that mastery experience is the dominant source of self-efficacy, which can also be attained through training. Vicarious experience emanates from observation, which can be achieved among others by watching teaching videos online, identified as a source of preservice teachers' self-efficacy (Karsenti and Collin, 2011). A study by Drago-severson (2002) revealed seven main professional development models for training teachers. These are observation, study groups, mentoring, individual guidance, in-service training, improvement process, and action research/inquiry. These added training models could make the difference between trained and untrained teachers. Kraut et al. (2016) study confirm the foregoing claim by establishing a positive relationship between professional training, teachers' self-efficacy, and performance. Moreover, Tschannen-Moran and McMaster, (2009) assert that follow-up coaching promotes mastery experience, influencing higher self-efficacy to implement new strategies. Therefore, it is no surprise that trained teachers have higher self-efficacy and thus an edge over untrained teachers.

Our study however shows no difference in the level of selfefficacy among native and non-native English teachers in the three TSES examined. In Korea, Choi and Lee (2016) found that teachers with minimum proficiency were highly unlikely to increase their English use in the classrooms even with high self-efficacy. Also, with low self-efficacy and high proficiency, English will not be taught to a desirable level. In TEFL, Chacón (2005), and Eslami and Fatahi (2008) confirm that teachers' selfefficacy varies based on tasks and teaching expectations and teachers' self-assessment of their language proficiency. In this study, one reason for this trend is that NNESTs could utilize several language teaching methods. Medgye (2011) calls it learner models, while Ehrman et al. (1990) call it language learning strategies. This superiorizes NNEST over NEST in most cases. Also, as Brutt-Griffler and Samimy (1999) revealed, although NNESTs face prejudice, resulting in them losing confidence in teaching, they could combine the various teaching methods within their reach to enhance their self-efficacy and performance. In the study by Reves and Medgyes (1994, p. 361), NNESTs showed "deeper insights into the English language" and seemed more qualified than NESTs. They showed more responsiveness towards their students and could predict the difficulties faced by their students. Discourse skills provides the means to teach English through English. This includes the ability to maintain communication in English (fluent, accurate and comprehensible) and more importantly, the extent to which the teacher can use English as a medium to teach English (Richards, 2017). Eslami and Fatahi (2008) study revealed a positive link between teachers' perceived level of language proficiency and sense of self-efficacy. Moreover, the higher the teacher's sense of self-efficacy the more they tend to employ communicative-based methods in their classes, and the proclivity to focus more on meaning rather than accuracy. This supports the argument that target language proficiency should not be associated with nativeness and that nativeness does not necessarily imply that teaching a language is the preserve of native speakers.

Evidence from various countries provide different findings on whether language proficiency levels affect teachers' self-efficacy in 
teaching English. While others indicate NESTs' strength in linguistic abilities, NNESTs have strength in pedagogy. In the view of the American Council on the Teaching of Foreign Languages (ACTFL), a foreign language teacher should have adequate competence in the hearing, understanding, speaking, reading, and writing of the target language (Omaggio and Higgs, 1984), which are the considered strengths of a NEST. In support of our findings too, Medgye (1992) notes that school administrators in France and England do not use nativeness as a basis for recruiting teachers. The study has identified no difference in the self-efficacy of NEST and NNEST in the teacher efficacy areas examined among the population studied.

\section{CONCLUSION}

It is worth noting that professionally trained and untrained teachers will continue to teach English in China, as will native and non-native English speakers because of the severe shortage of language teachers. The present study indicates that professionally trained teachers have a significant advantage in TEFL in China, confirming the findings of other professional training and selfefficacy studies. This supports the view that specific personal characteristics can influence self-efficacy. In this case, professional training determines teachers' self-efficacy in TEFL among the study group.

These findings provide evidence to support the theoretical propositions by Pasternak and Bailey (2004) that being prepared pedagogically and linguistically is essential and should be the paramount consideration in comprehending the professional status, growth, and practices of English teachers. Though this conclusion seems obvious, human resource managers should support the development of these skills, through in-service training, online learning, seminars and workshops, to advance their professional growth and development. Indeed, EFL teachers perceive technology as a vital learning tool in the 21st century to enhance pedagogical competence (Siregar et al., 2020). These are effective for promoting mastery experience, translating into higher self-efficacy beliefs which are critical in enhanced performance in classroom management, instructional strategies and student engagement activities.

However, linguistic ability does not mean nativeness. Nativeness and linguistic ability should not be used interchangeably. The two teacher characteristics should be treated separately and not as interchangeable constructs as done in previous research (Swanson, 2012). Levis (2020) makes a similar distinction between intelligibility and nativeness in language teaching and how each principle addresses teaching goals. These unique features are distinct and have varied influences on individuals. Therefore, our findings demonstrate how each characteristic provides a theoretical understanding of the TEFL profession and is a field of study worth considering further.

We recommend that policymakers amend the rules for language schools that require obtaining work permits for foreign teachers before they can teach legitimately. By making the requirements flexible, authorities could monitor and ensure that teachers who have work permits obtain the required training and certification within a specified period. The government could also identify and provide appropriate training on TEFL while making use of Chinese support staff. Even though studies have shown that schools and parents prefer foreign teachers to local Chinese teachers (see Rao and Yuan, 2016), it is important to restate Swanson (2012) conceptual distinction, namely; that nativeness should not be equated to linguistic ability. Schools and parents should therefore be encouraged to patronize Chinese-trained English teachers to fill existing teaching vacancies. We also recommend blending NEST with NNEST to provide a suitable situation and allow one group to make up for and plug the other's weaknesses (Selvi, 2011; Mannes and Katz, 2020). Despite the different attributes shown by both types of teachers, they complement each other. Students agree that collaborative teaching is better when addressing this dichotomous world of NESTs and NNESTs (Mhd Fauzi and Hashim, 2020). Finally, given that this study is situated in the Chinese cultural-context, and since culture plays a significant role in teachers' perceptions of themselves and their profession, we are constrained in widening the scope of application of the findings of our study. Additionally, the outbreak of Covid-19 limited the use of interviews and other qualitative research approaches in this study. We, therefore, recommend that future studies consider adopting a mixed-methods design in order to understand this phenomenon from another perspective. The insights from such an endeavor will be especially interesting to school administrators and policymakers.

\section{DATA AVAILABILITY STATEMENT}

The raw data supporting the conclusion of this article will be made available by the authors, without undue reservation.

\section{ETHICS STATEMENT}

The studies involving human participants were reviewed and approved by the ethics committee, University of Electronic Science and Technology of China. The patients/participants provided their written informed consent to participate in this study.

\section{AUTHOR CONTRIBUTIONS}

BG: contributed to the design of the study, collected data, and carried out the analysis. The content of the article was also drafted and proofread by the author. NK: contributed to the design of the study, and supported in collecting data. The content of the article was also proofread by the author. PA: contributed to the design of the study, and took part in the data analysis DK; Supported data collect and proofread the final draft of the paper MA: Proofread and edited the final part of the paper. 


\section{REFERENCES}

Anthony, T. D., and Kritsonis, W. A. (2007). A Mixed Methods Assessment of the Effectiveness of Strategic E-Mentoring in Improving the Self-Efficacy and Persistence (Or Retention) of Alternatively Certified Novice Teachers Within an Inner City School District. Natl. J. Publishing Monit. Doctoral Student Res. 4 (1), 1-8. Available at: https://doi.org/10.1.1.115.1006.

Aoyama, R. (2016). "One Belt, One Road": China's New Global Strategy. J. Contemp. East Asia Stud. 5 (2), 3-22. doi:10.1080/24761028.2016.11869094

Azari Noughabi, M., and Amirian, S. M. R. (2021). Assessing the Contribution of Autonomy and Self-Efficacy to EFL Teachers' Self-Regulation. English Teach. Learn. 45 (1), 71-88. doi:10.1007/s42321-020-00060-4

Bandura, A. (1977a). Self-efficacy: Toward a Unifying Theory of Behavioral Change. Psychol. Rev. 84 (2), 191-215. doi:10.1037/0033-295X.84.2

Bandura, A. (1997b). Self-efficacy: The Exercise of Control. New York: W. H. Freeman.

Bandura, A. (2006). "Guide for Constructing Self-Efficacy Scales," in Self-Efficacy Beliefs of Adolescents. Editors T. Urdan and F. Pajares (Greenwich, CT: Information Age

Bandura, A. (2010). "Self-Efficacy," in The Corsini Encyclopedia of Psychology. Editors I. B. Weiner and W. E. Craighead (Hoboken, NJ, USA: John Wiley \& Sons), 1-3. doi:10.1002/9780470479216.corpsy0836

Berger, J.-L., Girardet, C., Vaudroz, C., and Crahay, M. (2018). Teaching Experience, Teachers' Beliefs, and Self-Reported Classroom Management Practices: A Coherent Network. SAGE Open. 8 (1), 215824401775411-215824401775412. doi:10.1177/2158244017754119

Braine, G. (2018). "Non-Native-Speaker English Teachers," in The Encyclopedia of Applied Linguistics (New York: Wiley), 1-5. doi:10.1002/ 9781405198431.wbeal0871.pub2

Brown, H. D. (2001). "Teaching by Principles an Interactive Approach to Language Pedagogy," in Teaching by Principles an Interactive Approach to Language Pedagogy. Second Edi (New York: Longman).

Brutt-Griffler, J., and Samimy, K. K. (2001). Transcending the Nativeness Paradigm. World Englishes. 20 (1), 99-106. doi:10.1111/1467-971X.00199

Brutt-Griffler, J., and Samimy, K. K. (1999). Revisiting the Colonial in the Postcolonial: Critical Praxis for Nonnative-English-Speaking Teachers in a TESOL Program. TESOL Q. 33 (3), 413. doi:10.2307/3587672

Chacón, C. T. (2005). Teachers' Perceived Efficacy Among English as a Foreign Language Teachers in Middle Schools in Venezuela. Teach. Teach. Education. 21 (3), 257-272. doi:10.1016/j.tate.2005.01.001

Cheung, H. Y. (2008). Teacher Efficacy: A Comparative Study of Hong Kong and Shanghai Primary In-Service Teachers. Aust. Educ. Res. 35 (1), 103-123. doi:10.1007/BF03216877

Choi, E., and Lee, J. (2016). Investigating the Relationship of Target Language Proficiency and Self-Efficacy Among Nonnative EFL Teachers. System. 58, 49-63. doi:10.1016/j.system.2016.02.010

Clark, S. (2016). An Exploratory Study Examining the Influence of the Number of Reading Methods Courses on Pre-Service and In-Service Teacher Perceptions of Ability to Teach reading. Asia-Pacific J. Teach. Education. 44 (2), 125-141. doi:10.1080/1359866X.2015.1066492

Clark, S., and Newberry, M. (2019). Are We Building Preservice Teacher SelfEfficacy? A Large-Scale Study Examining Teacher Education Experiences. Asia-Pacific J. Teach. Education. 47, 32-47. doi:10.1080/ 1359866X.2018.1497772

Cochran-Smith, M., and Villegas, A. M. (2016). "Preparing Teachers for Diversity and High-Poverty Schools: A Research-Based Perspective," in Teacher Education for High Poverty Schools, Education, Equity, Economy. Editors J. Lampert and B. Burnett (Switzerland: Springer), 9-31. doi:10.1007/978-3319-22059-8_2

Davies, A. (2003). "The Native Speaker: Myth and Reality," in Bilingual Education and Bilingulaism. Editors C. Baker and N. H. Hornberger. 38th ed. (Clevedon, United Kingdom: Clevedon: Multilingual Matters).

Drago-severson, E. (2002). School Leadership in Support of Teachers' Transformational Learning: Paper Presented at the Annual Meeting of the American Educational Research Association. New Orleans: Louisiana.

Ehrman, M. E., Wenden, A., and Rubin, J. (1990). Learner Strategies in Language Learning. Mod. Lang. J. 74 (4), 509. doi:10.2307/328531
Eslami, Z. R., and Fatahi, A. (2008). Teachers' Sense of Self-Efficacy, English Proficiency, and Instructional Strategies: A Study of Nonnative EFL Teachers in Iran. Tesl-Ej. 11 (4), 1-19.

Faez, F., and Karas, M. (2017). Connecting Language Proficiency to (Self-Reported) Teaching Ability: A Review and Analysis of Research. RELC J. 48, 135-151. doi:10.1177/0033688217694755

Farrell, J. (2018). Shortage of English Teachers in China: Opportunities for Foreign Organizations and Teachers. Available at: https://daxueconsulting.com/englishteachers-in-china-opportunities/. April 24, 2019.

Gass, S. M., Behney, J., Plonsky, L., and Selinker, L. (2008). Second Language Acquisition 3rd ed. New York, NY: Routledge. doi:10.4324/9780203932841

Gibson, S., and Dembo, M. H. (1984). Teacher Efficacy: A Construct Validation. J. Educ. Psychol. 76 (4), 569-582. doi:10.1037/0022-0663.76.4.569

Gil, J. (2011). A Comparison of the Global Status of English and Chinese: Towards a New Global Language?. English Today. 27 (1), 52-59. doi:10.1017/ S0266078411000149

Goddard, R. D., Hoy, W. K., and Hoy, A.W. (2004). Collective Efficacy Beliefs: Theoretical Developments, Empirical Evidence, and Future Directions. Educ Res. 33 (3), 3-13. doi:10.3102/0013189X033003003

Gumah, B., Wenbin, L., and Aziabah, M. A. (2021). Supervisors' Leadership Styles' Influence on Foreign Teachers' Self-Efficacy in a Cross-Cultural Work Setting: A Moderated Mediation Analysis. SAGE Open. 11 (1), 215824402199454-2440. doi:10.1177/2158244021994546

Hajovsky, D. B., Chesnut, S. R., and Jensen, K. M. (2020). The Role of Teachers' Self-Efficacy Beliefs in the Development of Teacher-Student Relationships. J. Sch. Psychol. 82, 141-158. doi:10.1016/j.jsp.2020.09.001

Henson, R. K. (2001). "Relationships between Preservice Teachers' Self- Efficacy, Task Analysis, and Classroom Management Beliefs," in Annual Meeting of the Southwest Educational Research Association, New Orleans, LA.

Hoang, T., and Wyatt, M. (2021). Exploring the Self-Efficacy Beliefs of Vietnamese Pre-Service Teachers of English as a Foreign Language. System. 96, 102422. doi:10.1016/j.system.2020.102422

Hu, G. (2002). Potential Cultural Resistance to Pedagogical Imports: The Case of Communicative Language Teaching in China. Lang. Cult. Curriculum. 15 (2), 93-105. doi:10.1080/07908310208666636

Hu, G. (2005). English Language Education in China: Policies, Progress, and Problems. Lang. Pol. 4 (1), 5-24. doi:10.1007/s10993-004-6561-7

Jang, H., Reeve, J., and Deci, E. L. (2010). Engaging Students in Learning Activities: It Is Not Autonomy Support or Structure but Autonomy Support and Structure. J. Educ. Psychol. 102 (3), 588-600. doi:10.1037/a0019682

Kachru, B. B. (1997). World Englishes and English-Using Communities. Ann. Rev. Appl. Ling. 17, 66-87. doi:10.1017/S0267190500003287

Kraut, R., Chandler, T., and Hertenstein, K. (2016). La Relación entre Formación Docente, Acceso Recursos, Experiencia Docente y Desarrollo Profesional en la Autoeficacia Percibida por los Docentes en la Enseñanza de la Lectura en Inglés como Segunda Lengua. Gist. 12, 132-151. doi:10.26817/16925777.248

Landrum, T. J., and Kauffman, J. M. (2015). Behavioral Approaches to Classroom Management. Handbook Classroom Management., 47-71. doi:10.4324/ 9780203874783.ch3

Lazarides, R., Watt, H. M. G., and Richardson, P. W. (2020). Teachers' Classroom Management Self-Efficacy, Perceived Classroom Management and Teaching Contexts From Beginning until Mid-career. Learn. Instruction. 69, 101346. doi:10.1016/j.learninstruc.2020.101346

Levis, J. (2020). Revisiting the Intelligibility and Nativeness Principles. Jslp. 6 (3), 310-328. doi:10.1075/jslp.20050.lev

Li, D. (1998). "It's Always More Difficult Than You Plan and Imagine": Teachers' Perceived Difficulties in Introducing the Communicative Approach in South Korea. TESOL Q. 32 (4), 677. doi: $10.2307 / 3588000$

Ma, L. P. F. (2012). Strengths and Weaknesses of NESTs and NNESTs: Perceptions of NNESTs in Hong Kong. Linguistics Education. 23 (1), 1-15. doi:10.1016/ j.linged.2011.09.005

Maddux, J. E. (2002). "Self-efficacy," in Handbook of Positive Psychology. Editors C. R. Snyder and S. J. Lopez (New York: Oxford University Press), 277-287.

Mahboob, A. (2018). "NNEST Lens: Implications and Directions," in The TESOL Encyclopedia of English Language Teaching, 1-7. doi:10.1002/ 9781118784235.eelt0038

Mannes, A., and Katz, Y. J. (2020). The Professional Identity of EFL Teachers: The Complexity of Nativeness. Curric Teach. 35 (2), 5-24. doi:10.7459/ct/35.2.02 
Marczely, B. (1996). Personalizing Professional Growth. Staff Development that Works. Thousand Oaks; California: Corwin Press.

Medgyes, P. (1992). Native or Non-Native: Who's worth More?. ELT J. 46 (4), 340-349. doi:10.1093/elt/46.4.340

Mesthrie, R., and Bhatt, R. M. (2008). World Englishes: The Study of New Linguistic Varieties. Cambridge: Cambridge University Press. doi:10.1017/ CBO9780511791321

Mhd Fauzi, N., and Hashim, H. (2020). Apple vs. Mangosteen: A Qualitative Study of Students' Perception Towards Native and Non-Native English-Speaking Teachers. J. Education E-Learning Res. 7 (2), 218-228. doi:10.20448/ journal.509.2020.72.218.228

Morgan-Short, K., Sanz, C., Steinhauer, K., and Ullman, M. T. (2010). Second Language Acquisition of Gender Agreement in Explicit and Implicit Training Conditions: An Event-Related Potential Study. Lang. Learn. 60 (1), 154-193. doi:10.1111/j.1467-9922.2009.00554.x

Omaggio, A. C., and Higgs, T. V. (1984). Teaching for Proficiency, the Organizing Principle. Lincolnwood, Illinois: Lincolnwood, IL Natl. Textbook.

Olson, C. L. (1976). On Choosing a Test Statistic in Multivariate Analysis of Variance. Psychol. Bull. 83 (4), 579-579. doi:10.1037/0033-2909.83.4.579

Pasternak, M., and Bailey, K. M. (2004). Preparing Nonnative and Native EnglishSpeaking Teacherc: Lssues of Professionalism and Proffciency. Ann Arbor: University of Michigan Press.

Pillai, K. C. S. (1955). Some New Test Criteria in Multivariate Analysis. Ann. Math. Statist. 26 (1), 117-121. doi:10.1214/aoms/1177728599

Putri, N., and Refnaldi, R. (2020). Rewards and Punishments Given by the Teacher in Teaching English as Foreign Language in Indonesian Context. Jelt. 9 (1), 75. doi:10.24036/jelt.v9i1.107819

Rao, Z., and Yuan, H. (2016). Employing Native-English-Speaking Teachers in China: Benefits, Problems and Solutions. English Today 32 (4), 12-18. doi:10.1017/S0266078415000590

Reis, D. S., and Johnson, K. E. (2010). Non-native English-Speaking Teachers and Professional Legitimacy: A Sociocultural Theoretical Perspective on Identity Realization. Coll. Liberal Arts. 2011 (208), 139-160. doi:10.1515/ijsl.2011.016

Reves, T., and Medgyes, P. (1994). The Non-Native English Speaking EFL/ESL Teacher's Self-Image: An International Survey. System. 22 (3), 353-367. doi:10.1016/0346-251X(94)90021-3

Richard, M. (1985). Dictionary of Language Teaching and Applied Linguistics. London: Pearson Education Limited.

Richards, J. C. (2017). Teaching English Through English: Proficiency, Pedagogy and Performance. RELC J. 48 (1), 7-30. doi:10.1177/ 0033688217690059

Ross, J. A., Bradley Cousins, J., and Gadalla, T. (1996). Within-Teacher Predictors of Teacher Efficacy. Teach. Teach. Education. 12 (4), 385-400. doi:10.1016/ 0742-051X(95)00046-M

Rotter, J. B. (1966). Generalized Expectancies for Internal versus External Control of Reinforcement. Psychol. Monogr. 80 (1), 1-28. doi:10.1037/ h0092976

Schnuck, D. H., Pintrich, P. R., and Meece, J. L. (2014). "Motivation: Introductions and Historical Foundations," in Motivation in Education: Theory, Research and Applications. 4th ed. (NJEnglewood Cliffs: Prentice-Hall), 1-50.

Selvi, A. F. (2011). The Non-native Speaker Teacher. ELT J. 65 (2), 187-189. doi:10.1093/elt/ccq092

Shernoff, E. S., and Kratochwill, T. R. (2007). Transporting an Evidence-Based Classroom Management Program for Preschoolers with Disruptive Behavior Problems to a School: An Analysis of Implementation, Outcomes, and Contextual Variables. Sch. Psychol. Q. 22 (3), 449-472. doi:10.1037/10453830.22.3.449

Shum, A., Lau, P., and Fryer, L. (2020). From Learner to Teacher: (Re)training Graduate Teaching Assistants' Teaching Approaches and Developing SelfEfficacy for and Interest in Teaching. Higher Education Res. Development., 1-18. doi:10.1080/07294360.2020.1818063
Siregar, R. A., Fauziati, E., and Marmanto, S. (2020). An Exploration on Efl Teachers' Perceptions of Effective 21st-Century Pedagogical Competencies. Jeels. 7 (1), 1-24. doi:10.30762/jeels.v7i1.1548

Skaalvik, E. M., and Skaalvik, S. (2010). Teacher Self-Efficacy and Teacher Burnout: A Study of Relations. Teach. Teach. Education. 26 (4), 1059-1069. doi:10.1016/ j.tate.2009.11.001

Snow, C. E., Burns, M. S., and Griffin, P. (1998). Preventing Reading Difficulties in Young Children. Washington, DC: Department of Education, Washington, DC.

Sparks, D., and Loucks-Horlsey, S. (1989). Five Models of Staff Development. J. Staff Development.

Swanson, P. (2012). Second/Foreign Language Teacher Efficacy and its Relationship to Professional Attrition. Can. Mod. Lang. Rev. 68 (1), 78-101. doi:10.3138/cmlr.68.1.078

Tschannen-Moran, M., and McMaster, P. (2009). Sources of Self-Efficacy: Four Professional Development Formats and Their Relationship to Self-Efficacy and Implementation of a New Teaching Strategy. Elem. Sch. J. 110 (2), 228-245. doi:10.1086/605771

Tschannen-Moran, M., Hoy, A. W., and Hoy, W. K. (1998). Teacher Efficacy: Its Meaning and Measure. Rev. Educ. Res. 68 (2), 202-248. doi:10.3102/ 00346543068002202

Tschannen-Moran, M., and Hoy, A. W. (2001). Teacher Efficacy: Capturing an Elusive Construct. Teach. Teach. Education. 17 (7), 783-805. doi:10.1016/ S0742-051X(01)00036-1

Url, S., and Swanson, P. B. (2012). Teacher Efficacy and Attrition: Helping Students at Introductory Levels of Language Instruction Appears Critical. Hispania. 93 (2), 305-321.

Vinet, L., and Zhedanov, A. (2011). A 'Missing' Family of Classical Orthogonal Polynomials. J. Phys. A: Math. Theor. 44 (12), 085201. doi:10.1088/1751-8113/ $44 / 8 / 085201$

Wheatley, K. F. (2002). The Potential Benefits of Teacher Efficacy Doubts for Educational Reform. Teach. Teach. Education. 18 (1), 5-22. doi:10.1016/S0742051X(01)00047-6

Woolfolk Hoy, A., and Weinstein, C. S. (2015). "Student and Teacher Perspectives on Classroom Management," in Handbook of Classroom Management. Editors C. M. Evertson and C. S. Weinstein. 1st ed. (New York: Routledge). doi:10.4324/ 9780203874783.ch8

Wyatt, M. (2014). Towards a Re-Conceptualization of Teachers' Self-Efficacy Beliefs: Tackling Enduring Problems With the Quantitative Research and Moving on. Int. J. Res. Method Education. 37 (2), 166-189. doi:10.1080/ 1743727X.2012.742050

Zheng, J., and Zhang, Y. (2014). Foreign Teachers May See Tighter Requirements. Available at: http://www.chinadaily.com.cn/china/2014-09/16/content_ 18602809.htm (Accessed April 24, 2019).

Conflict of Interest: The authors declare that the research was conducted in the absence of any commercial or financial relationships that could be construed as a potential conflict of interest.

Publisher's Note: All claims expressed in this article are solely those of the authors and do not necessarily represent those of their affiliated organizations, or those of the publisher, the editors and the reviewers. Any product that may be evaluated in this article, or claim that may be made by its manufacturer, is not guaranteed or endorsed by the publisher.

Copyright $\odot 2021$ Gao, Gumah, Kulbo, Addo, Kulbo and Aziabah. This is an openaccess article distributed under the terms of the Creative Commons Attribution License (CC BY). The use, distribution or reproduction in other forums is permitted, provided the original author(s) and the copyright owner(s) are credited and that the original publication in this journal is cited, in accordance with accepted academic practice. No use, distribution or reproduction is permitted which does not comply with these terms. 